\section{Test of Bogartz's model on binary prediction by children}

\author{
SANDRA J. JONES \\ National Institute of Mental Health, Bethesda, Md. 20014
}

Sixty-four nursery Ss and 64 kindergarten Ss predicted the next event in sequences that were either predominantly alternating or repeating. There were 100 trials in acquisition. For the 100 transfer trials, the type of sequence was switched for half of the Ss. Bogartz's model represented the essential features of the data. These findings support his theory, which emphasizes attention and short-term memory processes and assumes the learning of rules rather than probabilities. Furthermore, the results demonstrate that his theory can be extended to situations where children must change rules.

Bogartz $(1966,1967,1969)$ has developed a theory and model for children's predictions of binary sequences. He assumes that attention and short-term memory processes determine the information available to children to make their trial-to-trial predictions, while a generator rule determines the response choice based on the information in the short-term store. It is assumed that the generator rule is acquired prior to or during the early trials of the experiment. Thus, Bogartz is proposing that children learn rules rather than probabilities in order to follow binary sequences.

The following is a brief summary of Bogartz's model. A more detailed and formal presentation of the model can be found elsewhere (Bogartz, 1969). Bogartz assumes that children's short-term memory store holds only the most recently passed trace. In the case of a binary situation, this could be the previous event, the previous response, or nothing. A response generator rule is then applied to the existing trace. As an example of how a child uses a generator rule, assume that the event sequence is an alternating one (or predominantly alternating) and that the child has acquired an alternation rule. If the child pays attention to the previous event and remembers it, he would predict the alternate event. If the child remembers the previous response, he would predict the alternate response. If he forgets both the previous event and response, he would guess. With a repetition sequence, a repetition rule would be used. Thus, the trace of a response or event would result in the prediction of the same, rather than the alternate, response or event on the next trial.

Bogartz has reported detailed fits of the model for prediction of single alternation sequences and also for tending to alternate and tending to repeat sequences. However, little is known about the application of the model in situations where the

Table 1

Relative Frequency of 3-Tuples

\begin{tabular}{|c|c|c|c|c|c|c|c|c|}
\hline & Group & Pred $_{\mathbf{I}}$ & $\operatorname{Pred}_{G}$ & Obs & Group & Pred $_{\text {I }}$ & Pred $_{G}$ & Obs \\
\hline $\begin{array}{l}\text { ccc } \\
\text { cce } \\
c e c \\
c e e \\
e c c \\
e c e \\
\text { eec } \\
\text { eee }\end{array}$ & $\mathrm{N}_{1}$ & $\begin{array}{l}.334 \\
.112 \\
.080 \\
.083 \\
.117 \\
.053 \\
.086 \\
.136\end{array}$ & $\begin{array}{l}.315 \\
.125 \\
.080 \\
.095 \\
.126 \\
.050 \\
.096 \\
.114\end{array}$ & $\begin{array}{l}.332 \\
.108 \\
.100 \\
.075 \\
.110 \\
.067 \\
.074 \\
.134\end{array}$ & $K_{1}$ & $\begin{array}{l}.498 \\
.080 \\
.038 \\
.056 \\
.086 \\
.015 \\
.060 \\
.167\end{array}$ & $\begin{array}{l}.512 \\
.083 \\
.031 \\
.066 \\
.085 \\
.014 \\
.067 \\
.143\end{array}$ & $\begin{array}{l}.514 \\
.082 \\
.035 \\
.062 \\
.084 \\
.015 \\
.061 \\
.147\end{array}$ \\
\hline $\begin{array}{l}c c c \\
c c e \\
c e c \\
c e e \\
\text { ecc } \\
\text { ece } \\
\text { eec } \\
\text { eee }\end{array}$ & $N_{11}$ & $\begin{array}{l}.376 \\
.108 \\
.079 \\
.077 \\
.112 \\
.050 \\
.080 \\
.117\end{array}$ & $\begin{array}{l}.362 \\
.125 \\
.082 \\
.086 \\
.125 \\
.043 \\
.086 \\
.090\end{array}$ & $\begin{array}{l}.380 \\
.107 \\
.087 \\
.081 \\
.108 \\
.061 \\
.080 \\
.096\end{array}$ & $K_{11}$ & $\begin{array}{l}.504 \\
.075 \\
.037 \\
.050 \\
.081 \\
.130 \\
.054 \\
.187\end{array}$ & $\begin{array}{l}.555 \\
.082 \\
.033 \\
.061 \\
.082 \\
.012 \\
.061 \\
.114\end{array}$ & $\begin{array}{l}.558 \\
.080 \\
.045 \\
.050 \\
.080 \\
.014 \\
.049 \\
.123\end{array}$ \\
\hline $\begin{array}{l}\text { ccc } \\
\text { cce } \\
\text { cec } \\
\text { cee } \\
\text { ecc } \\
\text { ece } \\
\text { eec } \\
\text { eee }\end{array}$ & $\mathbf{N}_{91}$ & $\begin{array}{l}.216 \\
.114 \\
.084 \\
.105 \\
.117 \\
.077 \\
.108 \\
.179\end{array}$ & $\begin{array}{l}.158 \\
.124 \\
.097 \\
.124 \\
.123 \\
.096 \\
.123 \\
.157\end{array}$ & $\begin{array}{l}.161 \\
.082 \\
.112 \\
.109 \\
.086 \\
.134 \\
.108 \\
.209\end{array}$ & $K_{91}$ & $\begin{array}{l}.322 \\
.090 \\
.035 \\
.085 \\
.094 \\
.033 \\
.089 \\
.252\end{array}$ & $\begin{array}{l}.289 \\
.094 \\
.031 \\
.094 \\
.091 \\
.030 \\
.091 \\
.279\end{array}$ & $\begin{array}{l}.263 \\
.065 \\
.026 \\
.100 \\
.066 \\
.055 \\
.094 \\
.331\end{array}$ \\
\hline $\begin{array}{l}\text { ccc } \\
\text { cce } \\
\text { cec } \\
\text { cee } \\
\text { ecc } \\
\text { ece } \\
\text { eec } \\
\text { eee }\end{array}$ & $\mathbf{N}_{9}$ & $\begin{array}{l}.362 \\
.124 \\
.109 \\
.072 \\
.129 \\
.059 \\
.075 \\
.072\end{array}$ & $\begin{array}{l}.334 \\
.139 \\
.117 \\
.079 \\
.140 \\
.058 \\
.080 \\
.054\end{array}$ & $\begin{array}{l}.362 \\
.107 \\
.127 \\
.070 \\
.114 \\
.085 \\
.070 \\
.064\end{array}$ & $K_{9}$ & $\begin{array}{l}.461 \\
.114 \\
.113 \\
.051 \\
.120 \\
.051 \\
.053 \\
.037\end{array}$ & $\begin{array}{l}.409 \\
.142 \\
.142 \\
.049 \\
.142 \\
.049 \\
.049 \\
.017\end{array}$ & $\begin{array}{l}.426 \\
.100 \\
.182 \\
.033 \\
.105 \\
.111 \\
.034 \\
.009\end{array}$ \\
\hline $\begin{array}{l}\text { ccc } \\
\text { cce } \\
\text { cec } \\
\text { cee } \\
\text { ecc } \\
\text { ece } \\
\text { eec } \\
\text { eee }\end{array}$ & $\mathrm{N}_{99}$ & $\begin{array}{l}.436 \\
.106 \\
.091 \\
.063 \\
.112 \\
.050 \\
.066 \\
.076\end{array}$ & $\begin{array}{l}.391 \\
.132 \\
.103 \\
.073 \\
.131 \\
.044 \\
.073 \\
.052\end{array}$ & $\begin{array}{l}.416 \\
.108 \\
.114 \\
.062 \\
.107 \\
.069 \\
.062 \\
.062\end{array}$ & $\mathbf{K}_{99}$ & $\begin{array}{l}.528 \\
.102 \\
.099 \\
.044 \\
.108 \\
.042 \\
.046 \\
.033\end{array}$ & $\begin{array}{l}.473 \\
.134 \\
.134 \\
.038 \\
.134 \\
.038 \\
.038 \\
.011\end{array}$ & $\begin{array}{l}.494 \\
.097 \\
.159 \\
.027 \\
.097 \\
.092 \\
.027 \\
.006\end{array}$ \\
\hline $\begin{array}{l}\text { ccc } \\
\text { cce } \\
\text { cec } \\
\text { cee } \\
\text { ecc } \\
\text { ece } \\
\text { eec } \\
\text { eee }\end{array}$ & $N_{19}$ & $\begin{array}{l}.241 \\
.122 \\
.108 \\
.098 \\
.126 \\
.087 \\
.101 \\
.118\end{array}$ & $\begin{array}{l}.151 \\
.132 \\
.132 \\
.116 \\
.133 \\
.116 \\
.116 \\
.102\end{array}$ & $\begin{array}{l}.201 \\
.078 \\
.151 \\
.099 \\
.082 \\
.172 \\
.098 \\
.119\end{array}$ & $\mathbf{K}_{19}$ & $\begin{array}{l}.325 \\
.125 \\
.120 \\
.079 \\
.130 \\
.076 \\
.081 \\
.064\end{array}$ & $\begin{array}{l}.282 \\
.148 \\
.148 \\
.078 \\
.148 \\
.078 \\
.078 \\
.041\end{array}$ & $\begin{array}{l}.281 \\
.092 \\
.224 \\
.054 \\
.100 \\
.180 \\
.056 \\
.013\end{array}$ \\
\hline
\end{tabular}

generator rule must change during the experiment or in situations that utilize preexisting rules of nursery children. The present paper reports on an application of Bogartz's model to data from a binary prediction situation with nursery and kindergarten children. The role of generator rules could be examined in two ways using these data. First, a transfer situation was used, making it necessary for the children to change their rule during the experiment. Second, sequences were employed that corresponded with suggested (Craig \& Myers, 1963; Derks \& Paclisanu, 1967) preexisting response tendencies of the nursery (repetition response tendency) and kindergarten (alternation response tendency) children. Thus, those children who were given a sequence corresponding with their existing 
Table 2

Mean Number of Runs of Errors

\begin{tabular}{lllllrrr}
\hline Group & Pred $_{I}$ & Pred $_{G}$ & Obs & Group & Pred $_{I}$ & Pred $_{G}$ & Obs \\
\hline $\mathrm{N}_{1}$ & $\mathbf{1 7 . 1 5}$ & $\mathbf{1 7 . 8 2}$ & $\mathbf{1 7 . 8 4}$ & $\mathrm{K}_{1}$ & 10.30 & $\mathbf{1 0 . 0 4}$ & $\mathbf{1 0 . 0 6}$ \\
$\mathrm{N}_{11}$ & $\mathbf{1 6 . 4 7}$ & $\mathbf{1 6 . 9 9}$ & 17.00 & $\mathrm{~K}_{1}$ & 9.60 & 9.60 & 9.62 \\
$\mathrm{~N}_{91}$ & $\mathbf{1 9 . 7 1}$ & $\mathbf{2 2 . 1 9}$ & $\mathbf{2 2 . 0 6}$ & $\mathrm{K}_{9}$ & 12.96 & 12.47 & 12.62 \\
$\mathrm{~N}_{9}$ & $\mathbf{1 8 . 9 0}$ & $\mathbf{1 9 . 8 9}$ & $\mathbf{1 9 . 8 4}$ & $\mathrm{K}_{9}$ & $\mathbf{1 7 . 2 4}$ & $\mathbf{1 9 . 2 5}$ & $\mathbf{2 1 . 6 2}$ \\
$\mathrm{N}_{99}$ & $\mathbf{1 6 . 3 2}$ & $\mathbf{1 7 . 6 7}$ & $\mathbf{1 7 . 6 9}$ & $\mathrm{K}_{9}$ & $\mathbf{1 5 . 1 0}$ & $\mathbf{1 7 . 2 8}$ & 18.81 \\
$\mathrm{~N}_{19}$ & $\mathbf{2 1 . 4 4}$ & $\mathbf{2 5 . 1 9}$ & $\mathbf{2 5 . 3 1}$ & $\mathrm{K}_{19}$ & $\mathbf{2 0 . 7 0}$ & $\mathbf{2 2 . 7 1}$ & $\mathbf{2 7 . 7 5}$ \\
\hline
\end{tabular}

response tendency would not have to learn a new generator rule during the early trials, while those children who were given a sequence that was opposite to their response tendency would have to learn a new generator rule. A detailed description of the methodology and summary statistics of the data have been reported elsewhere (Jones, 1970).

\section{METHOD}

The Ss were 64 nursery and 64 kindergarten children who were instructed to predict which of two red lights would come on for 200 trials by placing a white choice card in a slot under the predicted light. The Ss were tested one at a time and were told that this was a guessing game.

Sequences with repetition probabilities (probability of an event repeating itself) of .1 and .9 were chosen; the former results in an almost perfectly alternating pattern, while the latter involves extremely long runs of each event. The Ss were assigned randomly to one of eight experimental groups differing in repetition probability $\left(\pi_{1}\right)$ for acquisition (Trials 1-100), $\pi_{1}$ for transfer (Trials 101-200), and for age. There were $16 \mathrm{Ss}$ in each group, eight males and eight females. For the acquisition trials, $\pi_{1}$ was set at .1 for half the Ss at each age level ( $N_{1}$ and $K_{1}$ groups) and .9 for the other half $\left(\mathrm{N}_{9}\right.$ and $\mathrm{K}_{9}$ groups). For the transfer trials, $\pi_{1}$ was reversed for half of the $S s$ in each of the $\pi_{1}$-age acquisition groups, resulting in four transfer $\pi$ groups at each age level: nonreversed $N_{1}$ and $K_{11}$, nonreversed $N_{9}$ and $K_{9}$, reversed $N_{91}$ and $K_{91}$, and reversed $N_{19}$ and $\mathrm{K}_{1}$, .

\section{RESULTS AND DISCUSSION}

The predicted values were obtained by two different methods. The first uses the average of individual parameter estimates for each $\mathbf{S}\left(\operatorname{Pred}_{\mathrm{I}}\right)$ to obtain the predicted values. The second uses one set of parameters for each group of Ss (Pred $_{G}$ ) to obtain the predicted values.

The values for the predicted $\left(\right.$ Pred $\left._{\mathrm{G}}\right)$ and observed mean correct responses in 20-trial blocks were presented in a previous paper (Jones, 1970). This statistical analysis was found to represent the essential features of all the groups. For acquisition, there were no differences in terms of goodness of fit due to preexisting response tendencies. However, in the nonreversed transfer groups, the model fit closer for those groups whose sequence corresponded with their preexisting response tendencies. The model also tended to fit the data better for the nonreversed than for the reversed groups.

The remaining results for acquisition and transfer are presented in tabular form. Table 1 shows the relative frequency of the eight possible 3-tuples; Table 2 shows the mean number of runs of errors; Table 3 shows the mean values of the number of error runs; and Table 4 shows the mean values of the number of joint occurrences of two correct responses $k$ close fit of the model for both ages. However, the variability in the observed and predicted values is somewhat larger than that reported by Bogartz (1969) for Markov event sequences. When comparing the two trials apart. All of these results reveal a methods for computing the predicted means, it is evident that both methods give an adequate description of the results, although the fits are generally closer with the method of estimating the group parameter.

The best fits of the model were for those groups whose event sequence corresponded to their hypothesized preexisting response tendencies and for those groups who received the same event sequence in acquisition and transfer. Children in these groups did not have to learn a new rule in the beginning or during the course of the task. Therefore, the best fits occurred in situations where rule selection was not an important factor

In summary, these findings support Bogartz's theory of information processing in children and demonstrate the generality of the theory to situations that necessitate flexibility in rule usage.

\section{REFERENCES}

BOGARTZ, R. S. Test of a theory of predictive behavior in young children Psychonomic Science, 1966, 4, 433-434. BOGARTZ, R. S. Extension of a theory of predictive behavior in young children to the effects of intertrial interval duration. Psychonomic Science, 1967, 8, 521-522. BOGARTZ, R. S. Short-term memory in binary prediction by children: Some stochastic information processing models. In G. H. Bower and J. T. Spence (Eds.) The psychology of learning and motivation: Advances in research and theory. Vol. 3. New York: Academic Press, 1969.

Table 3

Mean Values of $r_{j}$, the Number of Error Runs of Length $j$

\begin{tabular}{|c|c|c|c|c|c|c|c|c|}
\hline & Group & Pred $_{\mathbf{I}}$ & Pred $_{G}$ & Obs & Group & Pred $_{\text {I }}$ & Pred $_{G}$ & Obs \\
\hline $\begin{array}{l}\mathbf{r}_{1} \\
\mathbf{r}_{2} \\
\mathbf{r}_{3} \\
\mathbf{r}_{4} \\
\mathbf{r}_{5}\end{array}$ & $\mathbf{N}_{1}$ & $\begin{array}{r}8.50 \\
3.94 \\
1.96 \\
1.05 \\
.59\end{array}$ & $\begin{array}{r}8.23 \\
4.43 \\
2.38 \\
1.28 \\
.69\end{array}$ & $\begin{array}{r}10.28 \\
3.41 \\
1.41 \\
.97 \\
.44\end{array}$ & $\mathbf{K}_{1}$ & $\begin{array}{r}4.18 \\
2.14 \\
1.23 \\
.77 \\
.50\end{array}$ & $\begin{array}{r}3.27 \\
2.20 \\
1.49 \\
1.00 \\
.68\end{array}$ & $\begin{array}{r}3.78 \\
2.38 \\
1.16 \\
1.12 \\
.44\end{array}$ \\
\hline $\begin{array}{l}\mathbf{r}_{1} \\
\mathbf{r}_{2} \\
\mathbf{r}_{3} \\
\mathbf{r}_{4} \\
\mathbf{r}_{5}\end{array}$ & $\mathbf{N}_{11}$ & $\begin{array}{r}8.42 \\
3.82 \\
1.88 \\
.97 \\
.52\end{array}$ & $\begin{array}{r}8.38 \\
4.25 \\
2.15 \\
1.09 \\
.55\end{array}$ & $\begin{array}{r}9.00 \\
4.38 \\
1.56 \\
.75 \\
.69\end{array}$ & $\mathbf{K}_{11}$ & $\begin{array}{r}4.11 \\
1.75 \\
1.00 \\
.66 \\
.46\end{array}$ & $\begin{array}{r}3.41 \\
2.20 \\
1.42 \\
.91 \\
.59\end{array}$ & $\begin{array}{r}4.44 \\
1.62 \\
1.31 \\
1.00 \\
.19\end{array}$ \\
\hline $\begin{array}{l}\mathbf{r}_{1} \\
\mathbf{r}_{2} \\
\mathbf{r}_{3} \\
\mathbf{r}_{4} \\
\mathbf{r}_{5}\end{array}$ & $N_{91}$ & $\begin{array}{r}8.83 \\
4.58 \\
2.50 \\
1.43 \\
.84\end{array}$ & $\begin{array}{r}9.87 \\
\mathbf{5 . 4 8} \\
\mathbf{3 . 0 4} \\
\mathbf{1 . 6 9} \\
.94\end{array}$ & $\begin{array}{r}11.25 \\
3.94 \\
2.56 \\
1.62 \\
.88\end{array}$ & $\mathbf{K}_{\mathbf{9}}$ & $\begin{array}{r}3.86 \\
2.64 \\
1.82 \\
1.27 \\
.90\end{array}$ & $\begin{array}{r}3.16 \\
2.36 \\
1.76 \\
1.32 \\
.98\end{array}$ & $\begin{array}{l}2.75 \\
1.81 \\
2.25 \\
1.62 \\
1.31\end{array}$ \\
\hline $\begin{array}{l}\mathbf{r}_{1} \\
\mathbf{r}_{2} \\
\mathbf{r}_{3} \\
\mathbf{r}_{4} \\
\mathbf{r}_{5}\end{array}$ & $\mathbf{N}_{9}$ & $\begin{array}{r}11.44 \\
4.15 \\
1.71 \\
.77 \\
.38\end{array}$ & $\begin{array}{r}11.93 \\
4.78 \\
1.91 \\
.77 \\
.31\end{array}$ & $\begin{array}{r}12.81 \\
4.19 \\
1.34 \\
.81 \\
.34\end{array}$ & $\mathrm{~K}_{9}$ & $\begin{array}{r}11.99 \\
3.27 \\
1.13 \\
.46 \\
.21\end{array}$ & $\begin{array}{r}14.34 \\
3.66 \\
.93 \\
.24 \\
.06\end{array}$ & $\begin{array}{r}18.28 \\
2.88 \\
.28 \\
.12 \\
.03\end{array}$ \\
\hline $\begin{array}{l}\mathbf{r}_{1} \\
\mathbf{r}_{2} \\
\mathbf{r}_{3} \\
\mathbf{r}_{4} \\
\mathbf{r}_{5}\end{array}$ & $\mathrm{~N}_{99}$ & $\begin{array}{r}9.74 \\
3.42 \\
1.49 \\
.73 \\
.38\end{array}$ & $\begin{array}{r}10.40 \\
4.28 \\
1.76 \\
.72 \\
.30\end{array}$ & $\begin{array}{r}11.50 \\
3.81 \\
1.12 \\
.56 \\
.25\end{array}$ & $\mathrm{~K}_{99}$ & $\begin{array}{r}10.56 \\
2.78 \\
.99 \\
.42 \\
.19\end{array}$ & $\begin{array}{r}13.50 \\
2.95 \\
.65 \\
.14 \\
.03\end{array}$ & $\begin{array}{r}16.12 \\
2.19 \\
.44 \\
.00 \\
.06\end{array}$ \\
\hline $\begin{array}{l}\mathbf{r}_{1} \\
\mathbf{r}_{2} \\
\mathbf{r}_{3} \\
\mathbf{r}_{4} \\
\mathbf{r}_{5}\end{array}$ & $N_{19}$ & $\begin{array}{r}11.32 \\
5.03 \\
2.41 \\
1.21 \\
.63\end{array}$ & $\begin{array}{r}13.55 \\
6.26 \\
2.89 \\
1.34 \\
.62\end{array}$ & $\begin{array}{r}15.50 \\
5.50 \\
2.38 \\
.62 \\
.31\end{array}$ & $\mathrm{~K}_{1}$, & $\begin{array}{r}12.58 \\
4.70 \\
1.91 \\
.82 \\
.37\end{array}$ & $\begin{array}{r}14.97 \\
5.10 \\
1.74 \\
.59 \\
.20\end{array}$ & $\begin{array}{r}22.31 \\
4.50 \\
.81 \\
.06 \\
.00\end{array}$ \\
\hline
\end{tabular}


Table 4

Mean Values of $C_{k}$, the Number of Joint Occurrences of $T$ wo Correct Responses $k$ Trials Apart

\begin{tabular}{|c|c|c|c|c|c|c|c|c|}
\hline & Group & Pred $_{\mathrm{I}}$ & Pred $_{G}$ & Obs & Group & Pred $_{\text {I }}$ & Pred $_{G}$ & Obs \\
\hline $\begin{array}{l}c_{1} \\
c_{2} \\
c_{3} \\
c_{4} \\
c_{5}\end{array}$ & $N_{1}$ & $\begin{array}{l}44.15 \\
40.58 \\
38.87 \\
37.82 \\
37.07\end{array}$ & $\begin{array}{l}43.57 \\
38.69 \\
37.16 \\
36.48 \\
36.02\end{array}$ & $\begin{array}{l}43.62 \\
42.31 \\
39.19 \\
38.97 \\
\mathbf{3 6 . 7 2}\end{array}$ & $\mathrm{K}_{1}$ & $\begin{array}{l}57.19 \\
52.48 \\
49.77 \\
48.00 \\
46.73\end{array}$ & $\begin{array}{l}58.90 \\
53.18 \\
49.89 \\
47.90 \\
46.61\end{array}$ & $\begin{array}{l}59.03 \\
53.84 \\
50.81 \\
49.12 \\
47.84\end{array}$ \\
\hline $\begin{array}{l}c_{1} \\
c_{2} \\
c_{3} \\
c_{4} \\
c_{5}\end{array}$ & $\mathbf{N}_{11}$ & $\begin{array}{l}47.88 \\
44.64 \\
43.08 \\
42.10 \\
41.37\end{array}$ & $\begin{array}{l}48.22 \\
43.52 \\
42.02 \\
41.32 \\
40.82\end{array}$ & $\begin{array}{l}48.25 \\
45.75 \\
43.44 \\
42.38 \\
41.62\end{array}$ & $K_{11}$ & $\begin{array}{l}57.32 \\
53.03 \\
50.39 \\
48.58 \\
47.23\end{array}$ & $\begin{array}{l}62.99 \\
57.56 \\
54.48 \\
52.64 \\
51.42\end{array}$ & $\begin{array}{l}63.19 \\
59.12 \\
56.44 \\
54.75 \\
54.06\end{array}$ \\
\hline $\begin{array}{l}c_{1} \\
c_{2} \\
c_{3} \\
c_{4} \\
c_{5}\end{array}$ & $N_{91}$ & $\begin{array}{l}32.64 \\
29.37 \\
27.90 \\
27.09 \\
26.55\end{array}$ & $\begin{array}{l}27.83 \\
24.93 \\
24.36 \\
24.08 \\
23.82\end{array}$ & $\begin{array}{l}24.25 \\
26.75 \\
21.38 \\
22.12 \\
20.00\end{array}$ & $K_{91}$ & $\begin{array}{l}40.75 \\
35.03 \\
32.06 \\
30.34 \\
29.25\end{array}$ & $\begin{array}{l}37.98 \\
31.37 \\
27.92 \\
26.07 \\
25.01\end{array}$ & $\begin{array}{l}32.31 \\
28.31 \\
25.94 \\
24.94 \\
23.94\end{array}$ \\
\hline $\begin{array}{l}c_{1} \\
c_{2} \\
c_{3} \\
c_{4} \\
c_{5}\end{array}$ & $\mathbf{N}_{9}$ & $\begin{array}{l}48.07 \\
46.09 \\
45.18 \\
44.54 \\
43.99\end{array}$ & $\begin{array}{l}46.74 \\
44.14 \\
43.45 \\
42.98 \\
42.52\end{array}$ & $\begin{array}{l}46.62 \\
47.97 \\
45.94 \\
44.78 \\
44.78\end{array}$ & $\mathrm{~K}_{9}$ & $\begin{array}{l}56.92 \\
56.22 \\
55.63 \\
55.05 \\
54.47\end{array}$ & $\begin{array}{l}54.50 \\
53.95 \\
53.40 \\
52.85 \\
52.30\end{array}$ & $\begin{array}{l}\mathbf{5 2 . 0 6} \\
59.62 \\
54.78 \\
56.56 \\
54.41\end{array}$ \\
\hline $\begin{array}{l}c_{1} \\
c_{2} \\
c_{3} \\
\varepsilon_{4} \\
c_{5}\end{array}$ & $N_{99}$ & $\begin{array}{l}53.63 \\
51.64 \\
50.58 \\
49.82 \\
49.20\end{array}$ & $\begin{array}{l}51.81 \\
48.46 \\
47.51 \\
46.95 \\
46.45\end{array}$ & $\begin{array}{l}\mathbf{5 1 . 8 8} \\
\mathbf{5 1 . 8 8} \\
49.94 \\
48.56 \\
49.56\end{array}$ & $\mathbf{K}_{99}$ & $\begin{array}{l}62.28 \\
61.35 \\
60.69 \\
60.05 \\
59.42\end{array}$ & $\begin{array}{l}60.06 \\
59.45 \\
58.85 \\
58.24 \\
57.63\end{array}$ & $\begin{array}{l}58.62 \\
64.00 \\
59.38 \\
61.31 \\
60.12\end{array}$ \\
\hline $\begin{array}{l}c_{1} \\
c_{2} \\
c_{3} \\
c_{4} \\
c_{5}\end{array}$ & $\mathbf{N}_{19}$ & $\begin{array}{l}35.88 \\
34.17 \\
33.40 \\
32.87 \\
32.42\end{array}$ & $\begin{array}{l}28.09 \\
27.80 \\
27.52 \\
27.24 \\
26.95\end{array}$ & $\begin{array}{l}27.88 \\
34.50 \\
29.38 \\
30.31 \\
29.19\end{array}$ & $\mathrm{~K}_{19}$ & $\begin{array}{l}44.58 \\
43.65 \\
43.06 \\
42.57 \\
42.11\end{array}$ & $\begin{array}{l}42.57 \\
42.14 \\
41.71 \\
41.28 \\
40.85\end{array}$ & $\begin{array}{l}37.31 \\
49.50 \\
41.81 \\
45.81 \\
43.25\end{array}$ \\
\hline
\end{tabular}

CRAIG，G. J., \& MYERS, J. L. A developmental study of sequential two-choice decision making. Child Development, $1963,34,483-494$.

DERKS P. L \& PACLISANU, M. L Simple strategies in binary prediction by children and adults. Journal of Experimental Psychology, 1967, 73 $278-285$

JONES. S. J. Children's two-choice learning of predominantly alternating and repeating sequences. Journal of Experimental Child Psychology, 1970, $10,344-362$. 